October 15, 2012

GEORGE AND MITT: Like Father, Like Son? Not quite

\title{
By Walt De Vries
}

From 1961 through 1967, Walter De Vries served George Romney as a campaign strategist during Romney's terms as Michigan governor; heading campaign research and strategy for three campaigns and as executive assistant in the office of the governor. He is co-author, with Lance Tarrance, of the "Ticket Splitters," a ground-breaking look at the behavior of independent voters. He also was the founder of the North Carolina Institute of Political Leadership.

Like after the first debate, sometime after the second debate with President Barack Obama and his Republican challenger Mitt Romney, one of Romney's surrogates and spin-misters or Mitt himself, will harken to Romney's father, the late Michigan Gov. George Romney to reinforce an aura of integrity around the GOP candidate.

After the first debate it was wife Ann who said that Mitt had written "Dad" on paper he had at the lectern. Mrs. Romney, described as choking up during a post-debate interview with CNN, said it signified that Mitt respected what his father "taught me and what kind of person you are and I'm going to honor that."

While that might make for some good post-debate spin, perhaps exploitation of his late father's memory and dramatic television, the conduct of Mitt Romney's presidential campaign is a far cry from the kind of campaign and conduct, as a public servant, I saw during the seven years I worked in George Romney's campaigns and served him as governor.

There are some similarities - and they are admirable. Both men's lives are characterized by energy and hard work. They both have been faithful to their religion, the primacy of family and ability to sell what he believes. Both were exempt from military service - George during World War II when he was Managing Director of the Automotive Council for War Production; and Mitt with draft exemptions as a student and Mormon missionary in France

But it is Mitt's behavior during this presidential campaign that is distinguishing - and not those of his father at all. Since 2005, when he first decided to seek the presidency, his political posture and positions have shifted in erratic and startling ways, to the right, to the middle, to the right and shifting still.

George Romney's strength as a politician and public officeholder was his ability and determination to develop and hold consistent policy positions over his life. While it seems that Mitt would say and do anything to close a deal - or an election. George Romney's constant mantra to those in and around his campaigns and his gubernatorial staff: "As you campaign, so shall you govern." 
$-2-$

When George Romney launched his first campaign for governor, facing an entrenched Democratic machine with strong labor backing, he determined he'd reach out to independent voters - those who voted for Democrats and Republicans - ticket-splitters. For George, how you campaigned really mattered. How you communicated with voters, the positions you took, the persons on your campaign staff, and those you took contributions from, were an extension of the candidate's personality.

George Romney reached out to voters in union halls and factory gates, a rare venue for GOP candidates back then and still now. He refused to engage in personal attacks and kept his campaigns issue-based.

Mitt Romney and the people around him see campaigns as television marketing and voters as targets to be manipulated. Voters, they believe, make up their minds late and will be swayed with saturation television advertising. The campaign managers seek - daily it seems - for a magic bullet to force on the electorate that will move undecided and weak voters to Romney. Policy papers, positions are rare and short on content and meaning.

I've tried to track Mitt Romney's shifts - some 180 degrees others 360 -- on key issues during the campaign. I've stopped at 30: abortion, stem-cell research; climate change and global warming; campaign finance; and equal pay for women are just a few.

George Romney was a political risk-taker. He fought for a new Michigan constitution that was narrowly approved, overhauled the administrative structure of the executive branch in Michigan and battled repeatedly for an income tax. His campaigns were uphill - particularly in 1964 when he faced the Lyndon Johnson national landslide. In that year he increased his plurality while the rest of the GOP ticket was crushed.

"As you campaign, so shall you govern." That lesson from father to son, seems to be lost in the win-at-any-cost fog of politics in the $21^{\text {st }}$ century. 